\title{
Pension System Reforms in the Republic of Macedonia: Expected Benefits and Challenges
}

\author{
Suzana Bornarova \\ Associate Professor, University of Ss Cyril and Methodious, \\ Faculty of Philosophy, Institute of Social Work and Social Policy \\ bornarova@fzf.ukim.edu.mk \\ Natasha Bogoevska \\ Assistant Professor, University of Ss Cyril and Methodious, \\ Faculty of Philosophy, Institute of Social Work and Social Policy \\ natasa.bogoevska@fzf.ukim.edu.mk \\ Svetlana Trbojevik \\ Assistant Professor, University of Ss Cyril and Methodious, \\ Faculty of Philosophy, Institute of Social Work and Social Policy \\ svetlet@fzf.ukim.edu.mk
}

Doi:10.5901/ajis.2013.v2n9p393

\section{Abstract}

The process of pension system reforms in the Republic of Macedonia has been initiated in 1993 due to deficits of the Pension and Disability Insurance Fund (PDIF), low fertility rates, demographic aging and high unemployment rates in the country. With the enactment of the new Law on Pension and Disability Insurance and series of its subsequent changes and amendments, in the period until 2000 a policy of growing restrictions in the management of the state pension system was in place.Pension and disability insurance in the Republic of Macedonia until 2006 used to belong to the Pay As You Go System (PAYG), based on inter-generational solidarity and financed through workers salary contributions. The key reform was the transformation of this PAYG system which entailed a line of challenges related to its solvency. The new system kept the PAYG go principle only in the first pillar, while the other two newly introduced pension pillars are financed through individual savings accounts. This paper is going to address the above pension system changes, focusing on both paradigmatic and parametric reforms. In addition, it attempts to present the subsequent challenges and expected benefits of these processes.

Keywords: pensions, pension system, paradigmatic reforms, parametric reforms

\section{Legal and Institutional Framework}

Pension and disability insurance in the country before 2006 used to belong to the Pay As You Go System (PAYG), based on inter-generational solidarity and financed through workers salary contributions. However, this PAYG system was transformed. The new system kept the PAYG principle only in the first pillar, while the other two newly introduced pension pillars are financed through individual savings accounts.

The new three pillar pension system is legally based on three different Laws. The first PAYG public pension pillar is based on the Law on Pension and Disability Insurance and its many subsequent changes since 1994. The second pension pillar was initiated with the adoption of the Law on Mandatory Fully Funded Pension Insurance in 2002 and its subsequent changes. Additionally, recently introduced voluntary third pension pillar is regulated with the Law on Voluntary Fully Funded Pension Insurance adopted in 2008.

Governance of the pension and disability insurance is split between several institutions. The Pensions and Disability Insurance Fund (PDIF) is in charge for the collection of the contributions from the first public pension pillar. The contributions in the second pension pillar currently can be paid only in two private pension funds (Nov Penziski Fond/NPF and KB Prvo Penzisko Drustvo) selected on an international public tender in July 2004. The licenses within the mandatory fully funded pension insurance were granted to two pension companies on April 4, 2005. Their approvals for 
pension fund management are granted for a 10-year period. The private pension companies and pension funds are under direct supervision of the public Agency for Supervision of Fully Funded Pensions Insurance (MAPAS). The National Bank of the Republic of Macedoniahas had the role of a custodian of pension assets in the first five years since the beginning of the reform, while afterwards it will be in charge of issuing the permit to an elected commercial bank. For the voluntary pension funds, the custodian can be a commercial bank that meets the requirements prescribed in the law. Finally, the MLSP is in charge of creation and supervision of the policy for pension and disability insurance. It is also responsible for the supervision of the work of MAPAS and PDIF (Bornarova, Gerovska-Mitev, 2009: 13-14).

\section{Parametric Reforms}

Due to deficits of the Pension and Disability Insurance Fund (PDIF), low fertility rates, demographic aging and high unemployment rates ${ }^{1}$, the Government of Republic of Macedonia initiated the process of reforms of the pension and disability insurance system early in 1993. With the enactment of the new Law on Pension and Disability Insurance and series of its subsequent changes and amendments, in the period until 2000 a policy of growing restrictions in the management of the state pension system was in place. To improve the solvency of the PDIF and to tighten eligibility criteria, a set of parametric reforms were implemented:

- Restrictive measures, introduced with the Law on Pension and Disability Insurance, that entered into force on January 1, 1994 regarding: retirement eligibility criteria, by instituting higher retirement age, i.e. from 60 to 63 years of age for men and from 55 to 60 years of age for women; estimation of the pension base by the average of all wages of all years of service, instead of the 10 most favorable ones; lowering of the replacement rate from 85\% to 80\%; as well as repeal of the possibility to "buy" years of contributions as an option for fulfilling the eligibility criteria for retirement.

- Another set of restrictive changes of the Law were introduced in 1995, revoking the social elements from the pension and disability insurance system: the right to financial allowance for care and support by others; right to using social standard funds by the beneficiaries and the right to the funds for improvement of the protection of the disabled.

- Amendments to the Law in 1996 introduced: calculation of valorization coefficients; minimum pensions; calculation of maximum pensions according to the wages in the non-economic sector in order to provide compatibility of all factors that influence the pension level.

- Amendments to the Law on Financial Working in 1997 had the biggest effect on improved financial balance of the PDIF. It provided for payment of big parts of the unpaid past contributions with $70 \%$ discount or in installments. Also, more efficient mechanism was established regarding payment of the current contributions for pension and disability insurance on $25^{\text {th }}$ in the month for the previous month at the latest (European Commission, 2007: 113).

These changes provided for the desired effects in short run in terms of the balance between incomes and expenditures in the pension system, reduced influx of new pensioners and pension levels, regularity in pension payments and budget transfers towards the PDIF. However, solving the challenges in the long run imposed the need to deepen the reform of the pension system in a direction of its gradual privatisation. The need for privatisation of the pension system was emphasised in many relevant documents and reports prepared in this period. The National Development Strategy for Macedonia prepared with UNDP support, refers to the need for Macedonia to pass over to a three-level pension and disability insurance system by emphasisingthat "The process of "tightening" the public fund that has been having deficit problems for a long time should go along with the spreading of private pension schemes..." (Macedonian Academy of Sciences and Arts, UNDP, 1997: 100-101). The same year, the document "Pension System in Macedonia: Recommendations for Reforms" prepared by the CARANA Corporation for USAID also recommended privatisation of the pension system to reduce the financial burden of the PDIF. It also pointed out the political challenges related to the pension system reforms that should be expected...."The reforms almost always encounter resistance, due to the fact that

\footnotetext{
${ }^{1}$ Enterprises did not paid contributions for their employees regularly. Dismissed workers who found employment in the non-formal sector were most often out of reach for the organs for payment of social contributions. To tackle these problems, the government was initially increasing the pension contributions and in parallel was liberalising the regulations for early and disability pensions to compensate for the increased unemployment in the country (Vucev, 2009: 266).
} 
"playing" with the pension may have expensive political consequences, to that is why policy makers are not always ready to take such a risk..." (CARANA, 1997:9).

As a result, starting from 1996, the approach towards the reform of the pension system was two-folded: on one side, continuation of the measures for strengthening of the stability of the state pension system through the parametric reforms, and on the other side, activities were initiated for the establishment of a new pension system that would provide for long-term solvency.

\section{Paradigmatic Reforms}

The introduction of the paradigmatic pension reform was initiated with the technical and financial support of the World Bank within the 9.8 million dollars loan SPIL. One of the two components in the SPIL refers to the reforms in the pension and disability insurance system. The 2000 Law on Pension and Disability Insurance established the legislative framework required for the new pension system based on the three pillars: 1) mandatory defined benefit pillar (reformed pay-as-yougo system); 2) mandatory fully funded pillar; and 3) voluntary fully funded pillar.

The first pension pillar covers the risk of old-age, disability and survivors pensions, as well as minimum amount of benefit. It encompasses all employees and all other beneficiaries covered by the pension scheme, including the selfemployed and agricultural workers. A person is entitled to an old-age pension when 64 (man) or 62 (women) and minimum 15 years of service. Total contribution rate is $21.2 \%$ of gross salary ${ }^{2}$. For those entering the second pillar, $7.42 \%$ of these are transferred from the PDIF to the second pillar (MLSP, 2008: 68). Those who do not fulfill these conditions cannot be included in the pension insurance. This pillar is in constant deficit subsidised by the state budget (Vucev, 2009: 267).

The second pillar is a mandatory individual capitalized savings system, which started operating on $1^{\text {st }}$ of January 2006. This insurance provides right to pension insurance in case of an old age, i.e. payment of old age benefit. Mandatory fully funded pension insurance covers persons that started working for the first time after January 1, 2003, i.e. younger generations, which provided for the gradual introduction of this system. ${ }^{3}$

In addition to the mandatory entrants in the new pension system, there is a possibility for voluntary entrance of current contributors but also others (not covered by the first two pillars) to the third voluntary pension pillar. This pillar sets no limitations as to the levels of contributions. Third pillar contributors may effectuate the right to old age pension 10 years before the legal pension age ( 54 for men and 52 for women). It also provides the possibilities for establishment of professional pension schemes. The third pillar started in 2008 (MLSP, 2008c: 69-70).

Prior to the introduction of this reform there was campaign period (2002-2006) when several public opinion surveys on the new pension system and pension reform were carried out. According to the World Bank's social assessment (as part of the SPIL project), focus groups which included employers and public officials were positive towards the planned reform (Donevska, Trbojevik, 2009). The focus groups of pensioners were skeptical of the reform, mainly because of the previous negative experience with 'private pyramidal schemes', as well as the prevailing trust towards the state as pension provider rather than the private sector. The MLSP has conducted a public awareness campaign under the name "Inform Yourselves about your Rights - The Decision is yours" in 2006 through broadcasting of TV commercials, publishing ads, newspaper banners and billboards and dissemination of informative brochures for employees and leaflets for employers, in Macedonian and Albanian language. The media campaign was followed by PR activities, such as press conferences, open events, interviews with the Minister of Labour and Social Policy, the Director of the PDIF and the Director of MAPAS and public presentations. However, it should be noted that the public campaign did not involve an expert-based debate regarding social risks in the new reformed pension system. Lack of such debate reduced the space for alternative country basedsolutions in regard to the pension specifics and characteristics. The prevailing general impression was that the reform was 'imposed' by IMF and World Bank arrangements, without taking into consideration

\footnotetext{
2 Financing of the contributory part of the social protection system has recently changed with the introduction of the Law on contribution for compulsory social insurance (Official Gazette, 142/08), and its implementation from 1st of January 2009. Among other changes, this Law introduced gradual reduction of the social contribution base for pension, health and unemployment insurance for 10 percentage points, namely from previous $32 \%$ to $22 \%$, between the period 01.01 .2009 till 01.01 .2011 . The reduce in contributions from a macroeconomic point of view was introduced to shrink the price of labour, with an expectation that it will contribute to an increased employment and transfer of the work force fromthe informal into the formal sectors of the economy.

${ }^{3}$ As of December 31st 2006 there were 128.031 members into the second pillar, which represents 31.5\% of all insured persons, or $14.35 \%$ of the active population (European Commission, 2007: 13).
} 
the social concerns of the population. Among the few who challenged this reform were the trade unions, but their impact can be described as 'too little, too late'. Trade unions were in favor of a voluntary, rather than mandatory second pillar. Despite trade unions' efforts to point out these problems by organizing a general strike in 2000, their activities did not have an impact on the political will and decisions (European Commission, 2007: 123-124).

\subsection{Expected Benefits from Paradigmatic Reforms}

Expected benefits from the reforms on national level are the improved solvency of the pension system, influence on the development of the capital, labour market and reduce in public expenditures on the long run. On individual level, increased pension security is expected, ${ }^{4}$ as capitally financed pension systems are more resistant to demographic changes. This will provide for amortisation and diversification of risks. Transparency and insight into individual accounts is additional benefit.

Expected benefits from the second pillar are: transferring part of the financial burden to the insurers; reducing the older people care expenses for the next generations; stabilised income of pensioners that will not be dependent on the demographic factors; increase in the individuals' work initiatives and social insurance to provide for their future; income will not be depended only on paid contributions in the previous years, but also on the income from interest rates, dividends and other investments (Vucev, 2009: 267-271).

Experts claim that it is too early to assess the returns from the pension system reform investments. Probably the best benefit of the undertaken pension reform can be seen in the improved institutional functioning, in terms of transparency of the institutions involved, as well as the contribution collection (Bornarova, 2010). Unfortunately, positive outcomes of the new pension system are not visible in the other aspects of the reform (European Commission, 2007: 117). So far, access to the pension system and exclusion of some vulnerable population groups from the second pillar are emphasised as key shortcomings in the reforms. Namely, older people continued to benefit only from the first pillar. Agricultural workers are also not covered with the second pillar since their contributions are registered according to their cadastral income, which is too low, and cannot be divided in the two pillars Additional vulnerable groups in relation to the pension insurance access include: unemployed people, redundant workers (laid-off workers), those working only with short-term employment contract for which the employees pay only personal tax, those working on the grey market, including particularly the ethnic groups (Roma, Albanians) who are far less likely to be in registered work, leading to increased risks of poverty in old age. Also, very frequent condition in the private sector (especially in the small and medium sized companies) is the underreporting of salaries, which contributes towards payment of the pension contribution to the minimally calculated base (and not on the real paid salary). This will have an effect on future pensions of huge number of people, who will retire with below the average or minimal pensions (European Commission, 2007: 122123). UNDP experts warned of this risk back in 1999 emphasising that the strength of the lobby for privatisation and funded schemes to replace pay-as-you-go state pensions should be tempered by acute concern about the implications for low-income earners and for income distribution. The three pillar schemes tend to erode the role of the stateguaranteed social protection and generate inequalities. Those with long-term, well-paid employment stand to benefit from such systems, but the poor and vulnerable who rely on more irregular or informal forms of employment are put at a disadvantage (UNDP, 1999: 62). Herein, there is no legislative framework for older people who are not recipients of pension or social assistance. ${ }^{5}$ In the international legislation and EU these older people are entitled to social pensions regulated within special Laws on Social Pensions (MTSP, 2008d: 16).

According to Gerovska-Mitev (2008:95) the emergence of the private sector in pension insurance in principle was supposed to improve the possibilities for better and more secure old age pensions. However, the compulsory private pension pillar is equally risky, both for the individual and for the society, especially due to: a) high administrative costs

\footnotetext{
${ }^{4}$ In 1992 average pension was 79\% of the average salary, while in 2007 only 55,5\% of the average salary. With the governmental intervention in 2008 average pension was slightly increased to $57.2 \%$ of the average salary (MTSP, 2008a: 22).

${ }^{5}$ Recent research on social exclusion targeting a representative sample of 1.339 older people, showed that 31.9\% aged 64+ are not pension beneficiaries. Majority of them are woman or belong to ethnic groups Roma, followed by Turks and Albanians, and with lowest educational attainments (Bornarova, Gerovska-Mitev, 2009: 15). Despite general and official estimations about the high coverage of the pension system, according to EC experts, more than 70,000 (or 31.1\%) people above the age of 65 are not covered with pension benefit (European Commission, 2007: 122).
} 
charged by pension companies, amounting to $7.9 \%$ from the contributions paid by the recipients; ${ }^{6}$ b) extensive (inadequately projected) flow of transfers from the first to the second pension pillar that resulted in significant increase in transition costs for this pension reform, which would be again a burden for all tax payers in the country; ${ }^{7} \mathrm{c}$ ) insufficiently developed financial instruments on the domestic markets where the pension fund could make investments. ${ }^{8}$

A future challenge for the sustainability of the pension system is the evasion of contributions due to rising number of pensioners and constantly decreasing work force. The number of employees to 1 pension beneficiary shows continuous decrease: from 3 in 1991, 2.0 in 1995, 1.5 in 2000 and 1.3 in 2005 (European Commission, 2007: 128). Dependency ratio (number of employees per 1 pension beneficiary) in 2004, 2005 and 2006 was 1.3, 1.3 and 1.6 respectfully (MLSP, 2008d: 67). The dependency ratio in 2007 was 1.4:1 (Vucev, 2009: 266).

\section{Policy Relative to Work Engagement of Pensioners}

Policies for support of older workers on the labour market, keeping older workers employed for extended periods of time through flexible work practices, gradual retirement, age management on the work place, are lacking. In addition to disregarding the needs of older workers prior to the retirement, the Macedonian legislation is also restrictive in terms of the work engagement of pensioners after retirement.

Since June 2006 until January 2009, pension beneficiaries could be part of the insurance system based on reestablished work relations or performing working activities, and could receive part of the pension at the same time (in amount of $30 \%, 50 \%$ and $70 \%$ of the pension leveldepending on the type of work engagement: full working hours or shortened - 4 or less working hours). For this work engagement a contribution for pension and disability insurance was paid on a higher basis than for the rest of the employees. With the changes and amendments of the Law on Pension and Disability Insurance (Official Gazette 161/08) applied as of $1^{\text {st }}$ of January 2009, this entitlement was abolished. With these changes the payment of pension is ceased for those pensioners who had entered in a work relation or perform independent working activities in Macedonia or abroad. For pension beneficiaries who have at least one year of contribution period after effectuation of the pension right, a new possibility was introduced for calculation of the pension level on the basis of pension length and wages. This enabled re-determination of the pension amount in cases of reestablished work relation (recognition of this period in the pension service).

This Law practically prevents pension beneficiaries to provide for additional income by work and is not wellmatched with the promotion of the active ageing concept and quality of life in old age. International experiences speak of Laws for Pensioners' Employment that provide for legal income from working activities of pensioners and subsequently contribute to the increase in their living standard (MTSP, 2008d: 16).

The legislative changes prohibiting and demotivating work in old age were subject of critics. There were some statements by older people criticizing this move of the government in the media, but more organised reaction by the older people organisations was missing. This is due to the lack of strong, powerful and influential older people organisations that would represent them and advocate for their rights, needs and interests. The current government made several "smart" but rather populist moves to gain the affection of the retired persons given their significance as electorate, such as: increase in pensions, free of charge spa rehabilitation and public transport on Fridays. However, for these and all the other measures that affect and concern their lifes, older people have not been more substantially neither consulted nor involved in policy-making (Bornarova, 2010: 5). In this respect Vucev points out that all the actors directly involved with the pension system should increasingly participate in decision-making through direct social dialogue. This trend in Macedonia should be more visible and those who lack access to pension system should be incorporated (Vucev, 2009: 277-278).

${ }^{6}$ Comparatively, the administrative charges in Macedonia are high (i.e. Croatia up to 0.8\%, in Hungary 5-6\%) (European Commission, 2007: 13).

${ }^{7}$ There was an increase of the initially planned transitional costs (2.2\% from the GDP in case of 86,000 switchers i.e. $25 \%$ of the insured persons). As the numbers of switchers in the second pillar doubled the expectations, it implies that the transitional costs will also double, peaking to 4.5\% from the GDP in 2025-2030 (European Commission, 2007: 13).

${ }^{8}$ The currently low economic potential of the country, lack of foreign direct investments, the high rate of unemployment, as well as risky geographical surrounding, make projected gains from the investments of the funds in the second pillar questionable. At the moment, bank deposits are almost the only available financial asset. 


\section{The latest changes of pension system legislation}

Considering that the process of the reform caused several changes and amendments to the Law on Pension and Disability Insurance and on the other hand the implementation of the second pillar led to changes in the relevant laws, there was an evident need to adopt a new Law that will clearly define the rights from the first and second pillar. Also, the new business processes, particularly on personal evidence, caused the need to establish an integrated system of legal regulation of the data for contributors and beneficiaries of pension and disability insurance rights. This imposed the need to incorporate the provisions of personal evidence of the contributors and the beneficiaries in the new Law on Pension and Disability Insurance.

Thus in 2012 the Macedonian Parliament adopted a new Law on Pension and Disability Insurance, which follows on the previously planned reforms on the established three pillar pension system. The first and second pillar remain compulsory and are based on two components: solidarity characteristic for the first pillar and funded component associated with the second pillar.

The Law passed in 2012 has no specific news and as rights on pension and disability insurance once again determines:

- $\quad$ The right to retirement;

- Disability pension;

- The right to vocational rehabilitation and appropriate allowances;

- The right to family pension;

- $\quad$ Right to compensation for physical damage, and

- Right on minimal pension.

Regarding the right of retirement there are no changes in the terms and conditions for its acquisition. The old-age pension is acquired by age of 64 years (men) or 62 years (women) with minimum 15 years of service. The Law only reduces the age limit of the insured who work in jobs placements where service is calculated with increased length.

Unlike the previous solution where the disability was defined as a general or professional inability to work, now the rights on the basis of disability is also determined on the basis of the percentage of disability. Namely, this article defines disability as final and lasting changes in health status of the insured person, changes which can be altered in terms of reestablishing the former working abilities. Accordingly, an essential component in the assessment of disability is the final and lasting status of the specified condition, which significantly differs from temporary incapacity for work. It is significant that the Law provides deployment on another job placement or provision of part-time work for the insured, in cases in which reduction of working capacity is determined by $50 \%$ in accordance to the general labor regulations.

The new law regulates the procedure of determining the pension base and the percentage of determining disability pension which remained unchanged, compared to the previous solutions.

Having in mind that the second pillar has been implemented since 2006 there are no significant changes except for the additional updates in line with the existing system of the second pillar.

\section{Challenges for the future}

In the Republic of Macedonia the pension and disability insurance are governed by set of the following laws: the Law on Pension and Disability Insurance Insurance, Law on Mandatory Fully Funded Pension Insurance, Law on Voluntary Fully Funded Pension Insurance and the Law on Payment of Pensions and Pension benefits from the Fully Funded Pension Insurance. Given that the data on contributors and beneficiaries of pension and disability insurance is an important part of the pension system this area is regulated by the Law on Personal Registry of Contributors and Beneficiaries of Rights from Pension and Disability Insurance.

Macedonian pension system was based on PASYG principle. Due to the fears for unsustainable of the system as a result of demographic changes in Macedonia the Government decided to introduce radical systemic changes in the pension and disability insurance. Over the years a number of paradigmatic and parametric reforms were introduced. The most significant of them is the structural reform of introducing a three pillar pension system, implemented since January 2006. This is considered as one of the most an important segment of the social policy changes in the country. Despite the reasons used to justify the reform according to some expert opinions the reformed pension system is facing challenges in a long run.

It is expected that the reforms in the pension system will have an indirect influence on social stratification of elderly person. Macedonia as a country that has accepted the three-pillar system might experience a big gap in its social stratification in the future due to differences in the accumulated amounts and the number of pillars (some might never 
invest in the third pillar) where individuals have invested their savings. But social stratification should not be the only concern related to this change in the social protection system imposed by World Bank. Another alarming dimension is the inability to predict fluctuations in the market where savings from the second and third pillar are invested. Currently, their instability is connected to the global economic crises. This represents a risk for smaller countries, such as Macedonia, because, unlike the others, they do not have the capacity to protect their investments outside their domestic borders. This instability of pension savings will most likely jeopardize the once guaranteed security connected to the risk of old age and could violate the principle of social justice. Apart from demographic reasons, the pension reforms could be a reason for the unnecessary involvement of social policy with this age group. Finally, it should also be noted that the concept of the three-pillar system implies a direct attack on the intergenerational social solidarity that has been nurtured for over a century (Donevska, Trbojevik, 2009).

\section{References}

Bornarova S., (2010). Development of the Social Protection System in Post-Communist Macedonia: Social Policy-Making and Political Processes. In: Stambolieva M., (ed.) Welfare States in Transition: 20 years after the Yugoslav welfare model, Sofia: Friedrich Ebert Foundation Office Bulgaria

Bornarova, S., Gerovska-Mitev, M. (2009). Social Exclusion, Ethnicity and Older People in Macedonia. Faculty of Philosophy. ERSTE Stiftung.

Bornarova, S. (2010). Older People in the Reforms of the Social Welfare in Macedonia: Social Services Perspective. Paper presented at the VIII National Congress of Gerontology. Gerontological Society of Srbija. Vrnjacka Banja. 21-23 May 2010.

CARANA (1997). Pension System of Macedonia: Recommendations for Reforms. USAID. Skopje.

Donevska, M., Trbojevik, S. (2009). The Influence of Global Financial Institutions on the Development of Welfare in South Eastern Europe and their Impact on Social Work. In. Leskosek, V. (ed). Theories and Methods of Social Work-Exploring Different Perspectives. Faculty of Social Work, University of Ljubljana.

European Commission (2007). Social Protection and Social Inclusion in the FYRM. Directorate-General for Employment, Social Affairs and Equal Opportunities.

Gerovska-Mitev, M. (2008). Reform Processes and Challenges in the Social Policy in Macedonia. In Gerovska-Mitev, M. (ed.) Reframing Social Policy: Actors, Dimensions and Reforms. Faculty of Philosophy, Friedrich Ebert Stiftung.

Macedonian Academy of Sciences and Arts, UNDP (1997). National Development Strategy for Macedonia: Development and Modernisation.

MLSP (2008). Social Situation in Macedonia.

MLSP (2008a). Statistical Data on Social Assistance Beneficiaries in 2008.

MLSP (2008b). On the Path towards the EU: The Contribution of the Civil Society in the Creation of Social Inclusion Policy in Macedonia. Austrian Development Cooperation.

UNDP (1999). Human Development Report for Europe and the CIS. Transition 1999.

Vucev, Z. (2009). Inequalities in the Coverage and Pension System Rights in the Republic of Macedonia. In Gerovska Mitev, M. (2009). Social Policy Journal. 2/No3. Friedrich Ebert Stiftung.

Law on Pension and Disability Insurance (Official Gazette of the Republic of Macedonia 80/93, 3/94, 14/95, 71/96, 32/97, 24/2000, 96/2000, 50/2001, 85/2003, 50/2004, 4/2005, 84/2005, 101/2005, 70/2006, 153/2007, 152/2008, 161/2008, 81/2009, 156/2009, $24 / 11,51 / 11$ and $11 / 12)$

Law on Mandatory Fully Funded Pension Insurance (Official Gazette of the Republic of Macedonia No 29/02, 85/03, 40/04, 113/05, $29 / 07,88 / 08,48 / 09,50 / 10,171 / 10$ and 36/11)

Law on Voluntary Fully Funded Pension Insurance (Official Gazette of the Republic of Macedonia No 7/2008, 124/2010 and 17/2011) 